Original Article

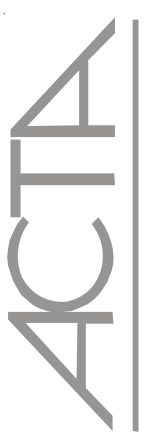

\section{Classification of patients seen at a hemodynamics unit according to the degree of dependence on nursing care*}

\author{
Classificação de pacientes atendidos em uma unidade de hemodinâmica segundo o grau de \\ dependência dos cuidados de enfermagem
}

Clasificación de pacientes atendidos en una unidad de hemodinamia según el grado de dependencia de los cuidados de enfermería

\begin{abstract}
Objective: To classify patients in a hemodynamics healthcare unit, according to the degree of dependence on nursing care. Methods: Cross-sectional study performed in June/2005 at the Hemodynamics unit of a university hospital. Data were collected during the first hour post-procedure, using Perroca's instrument of patient classification. Results: Among 164 patients, $52 \%$ were female, aged $60 \pm 14.8$ years. The average score of classification was $31.9 \pm 4.8$, rated as intermediate. As for instrument indicators, patients submitted to gastroenterological procedures presented a significant difference regarding their level of consciousness $(\mathrm{P}<0.0001)$; as for motility, patients submitted to cardiologic procedures presented higher dependence scores $(\mathrm{P}<0.0001)$; there were no differences for locomotion between the different specialties. Conclusion: The dependence profile of patients seen in the hemodynamics unit was considered intermediate. Further studies may add more information when planning the size of hemodynamics units.
\end{abstract} Keywords: Assessment of needs; Nursing care; Nursing staff, hospital

\title{
RESUMO
}

Objetivo: Classificar pacientes em uma unidade de hemodinâmica segundo o grau de dependência dos cuidados de enfermagem. Métodos: Estudo transversal, realizado em junho/2005 na hemodinâmica de um hospital universitário. A coleta de dados foi na primeira hora pós-procedimento, com o instrumento de classificação de pacientes de Perroca. Resultados: Dos 164 pacientes, $52 \%$ eram do sexo feminino, com média de idade de $60 \pm$ 14,8 anos. O escore médio da classificação foi de 31,9 \pm 4,8 pontos, categorizado como intermediário. Quanto aos indicadores do instrumento, pacientes submetidos a procedimentos gastroenterológicos apresentaram diferença significativa quanto ao nível de consciência (P<0,0001); quanto à motilidade, pacientes submetidos a procedimentos cardiológicos apresentaram escores maiores de dependência $(\mathrm{P}<0,0001)$; a locomoção não apresentou diferença entre as especialidades. Conclusão: $O$ perfil de dependência dos pacientes atendidos na hemodinâmica foi de grau de dependência intermediário. Novos estudos poderão agregar mais informações para o planejamento de dimensionamento em unidades de hemodinâmica. Descritores: Determinação de necessidades de cuidados de saúde; Cuidados de enfermagem; Recursos humanos de enfermagem no hospital

\section{RESUMEN}

Objetivo: Clasificar pacientes en una unidad de hemodinamia según el grado de dependencia de los cuidados de enfermería. Métodos: Se trata de un estudio transversal, realizado en junio/2005 en la unidad de hemodinamia de un hospital universitario. La recolección de datos se llevó a cabo en la primera hora después del procedimiento, con el instrumento de clasificación de pacientes de Perroca. Resultados: De los 164 pacientes, $52 \%$ eran del sexo femenino, con un promedio de edad de $60 \pm 14,8$ años. El puntaje medio de la clasificación fue de 31,9 \pm 4,8 puntos, clasificado como intermedio. En cuanto a los indicadores del instrumento, los pacientes sometidos a procedimientos gastroenterológicos presentaron diferencia significativa en cuanto al nivel de conciencia $(\mathrm{P}<0,0001)$; en cuanto a la motilidad, los pacientes sometidos a procedimientos cardiológicos presentaron puntajes mayores de dependencia $(\mathrm{P}<0,0001)$; la locomoción no presentó diferencia entre las especialidades. Conclusión: El perfil de dependencia de los pacientes atendidos en la unidad de hemodinamia fue de grado de dependencia intermedia. Estudios nuevos que se realicen podrán agregar más información para la planificación de acciones en las unidades de Hemodinamia.

Descriptores: Determinación de necesidades de cuidados de Salud; Cuidados de enfermería; Recursos humanos de enfermería en el hospital

\footnotetext{
* This study was performed at the Hospital São Lucas, of the Pontificia Universidade Católica do Rio Grande do Sul- PUCRGS - Porto Alegre (RS), Brazil; presented as a monograph in the Nursing Cardiology postgraduate course of the Fundação Universitária de Cardiologia, to obtain the title of Cardiology Specialist Nurse.Porto Alegre (RS), Brazil.

1 Specialist in cardiology by the Rio Grande do Sul Fundação Universitária de Cardiologia; specialist in Nursing Service Management by the Universidade Federal do Rio Grande do Sul-UFRGS-Porto Alegre (RS), Brazil.

${ }^{2}$ PhD, Adjunct Professor of the Nursing School at Universidade Federal do Rio Grande do Sul-UFRGS-Porto Alegre (RS), Brazil; Faculty member of the Cardiology Nursing Post graduation Program of the Fundação Universitária de Cardiologia.Porto Alegre (RS), Brazil.

${ }^{3}$ Faculty member of the Cardiology Nursing Post graduation Program of the Fundação Universitária de Cardiologia.Porto Alegre (RS), Brazil.

${ }^{4}$ Faculty member of the Cardiology Nursing Post graduation Program of the Fundação Universitária de Cardiologia.Professor of the Nursing undergraduate course of the IPA Centro Universitário Metodista.Porto Alegre (RS), Brazil.
} 


\section{INTRODUCTION}

The dimensioning of nursing human resources implies identifying and characterizing the clientele, regarding the demand of their needs ${ }^{(1)}$. This requirement happens because, more than healthcare attributions, the nurse is also assigned to administrative duties such as dimensioning the nursing team. Nowadays there are several proposals for patient classification systems, which may be used when calculating the size of personnel. These classifications are based on the patient's progressive healthcare levels ${ }^{(2)}$.

The System of Patient Classification (SPC) allows for planning the needs of groups of patients, providing greater satisfaction, higher productivity and higher efficiency at work, allied to shorter hospital stays ${ }^{(3)}$. The instrument of patient classifications, elaborated in 1998, is made up of 13 critical healthcare indicators, including: Mental State and Level of Consciousness, Oxygenation, Vital Signs, Nutrition and Hydration, Motility, Locomotion, Body Care, Eliminations, Therapeutics, Healthcare Education, Behavior, Communication and Skin-Mucosa Integrity, focusing on increasing intensities of healthcare complexity ${ }^{(4)}$.

In this instrument, the author demonstrates enough evidence of reliability and validity, indicating that it can be used as a diagnostic-instrument of the healthcare categories that the patient is subjected to, being feasibly applied within the nursing management practices as an indicator of the real healthcare needs, as well as to calculate the workload of the nursing team ${ }^{(5)}$.

In the vascular area context, the hemodynamics unit developed different characteristics and has been a place where specialties other than Cardiology have performed diagnostic and therapeutic exams.

A unit with an interventionist cardiologic laboratory performing extracardiac endovascular procedures can be considered of high-complexity ${ }^{(6)}$. The patients staying in the recovery rooms in these units may present different degrees of severity. Therefore, the classification of these patients, according to their healthcare needs, could support the guarantee of high-quality healthcare when dimensioning the nursing team.

Since studies on the classification of patients in hemodynamics units, according to their degree of dependence on nursing care in different specialties, are scarce in Brazilian literature, the authors were encouraged to develop this study, aiming to classify patients who received healthcare in a hemodynamics unit according to their degree of nursing care dependence.

\section{METHODS}

This is a cross-section study performed in the recovery room of the hemodynamics unit of a general hospital in Porto Alegre, Rio Grande do Sul State. This unit receives patients who have already been submitted to diagnostic exams and those who will still undergo those exams and therapeutic procedures in cardiological, vascular, gastroenterological, and neuroradiological areas. The patients receiving care are part of the internal demand of this institution (hospitalization, emergency and intensive therapy units), as well as of the outpatient clinic.

Considering a $33 \%$-proportion for the three most frequent healthcare groups (minimal, intermediate and semi-intensive), with a 10\% safety margin, 0.05 alpha and 0.20 beta, the sample size was estimated in 127 patients, all included, with 164 being analyzed and classified in the period of study.

The population was made up of adult inpatients staying in the recovery rooms in the hemodynamics unit. The sample included patients of the same unit, cared for during a two-week period. Inpatients who had been submitted to hemodynamic procedures and those who would still be submitted to the procedures were part of the sample, as well as those elected to undergo such procedures but who had not done so due to lack of rooms, still needing nursing care - a usual occurrence in this kind of service.

Twenty-three patients who had stayed in the recovery room for less than 2 hours and four patients under 18 years of age were excluded from the study.

The data were collected daily in a two-week period by the researcher, from 7 AM to 8 PM (working hours of the sector), with the application of Perroca's instrument of classification ${ }^{(4)}$.

The instrument of patient classification was created by Perroca (2002), and has been tested and validated. It consists of single-alternative questions numbered from 1 to 5 , according to the basic needs assessed. The assessment of the necessary type of healthcare was classified according to the following score: minimal healthcare: 13 to 26 points - healthcare to stable patients from a nursing viewpoint, but physically self-sufficient regarding basic human needs; intermediate healthcare: 27 to 39 points healthcare to stable patients from clinical and nursing viewpoints, partially dependent on nursing actions to satisfy basic human needs; semi-intensive healthcare: 40 to 52 points - healthcare to chronic patients, considered clinically stable, but totally dependent on nursing actions to satisfy their basic human needs; intensive healthcare: 53 to 65 points - healthcare to critical patients, in imminent risk of death, subject to unstable vital signs, requiring permanent and specialized nursing care.

This study was approved by the Research Ethics Committee of the institution, and a term of consent was used, allowing for the utilization of data from the patients' medical records. 
Data analysis was performed by means of descriptive analysis, with the software Statistical Package for Social Sciences 12.0. The descriptive data were presented with averages, standard deviation and absolute and relative frequencies. Student's $t$ test and ANOVA were used for comparative analyses, and Pearson's coefficient was used for correlations. Pd" 0.05 was considered statistically significantly.

\section{RESULTS}

Considering 164 patients with average ages of $60 \pm$ $14.8,52.4 \%$ were female, $51.2 \%$ had been submitted to cardiac catheterism, followed by vascular at $24 \%$, neuroradiology at $4.9 \%$ and, lastly, gastroenterology at $4.3 \%$, with local anesthesia being used more frequently $(65.9 \%)$ (Table 1).

Table 1 - Profile of the patients seen in a hemodynamics unit according to specialty and type of procedure

\begin{tabular}{lc} 
& $(\mathrm{n}=164)$ \\
\hline Variables & $\mathbf{n ~ ( \% )}$ \\
\hline Gender & $86(52,4)$ \\
Female & $60 \pm 14,8$ \\
Age* & \\
Specialty & $109(66,5)$ \\
Cardiology & $40(24,4)$ \\
Vascular & $8(4,9)$ \\
Neurorradiology & $7(4,3)$ \\
Gastroenterology & \\
Procedure & $84(51,2)$ \\
Cardiac Catheterism & $24(14,6)$ \\
Angioplasty & $23(14,0)$ \\
Arteriography & $8(4,9)$ \\
Definitive Pacemaker & $7(4,3)$ \\
Electrophysiological study & $7(4,3)$ \\
Colangiopancreatography & $4(2,4)$ \\
Draining/ Nephrostomia & $4(2,4)$ \\
No exams & $3(1,8)$ \\
Ablation & \\
Type of anesthesia & $1(0,6)$ \\
General & $108(65,9)$ \\
Local & $3(1,8)$ \\
Sedation & $48(29,3)$ \\
Local + sedation & $4(2,4)$ \\
No anesthesia & \\
n (\%) - category variables & \\
$*$ Data presented as average and standard deviation, in years.
\end{tabular}

Table 2 displays the distribution of patients according to their degree of dependence on nursing healthcare in each of the critical indicators evaluated. It is clear that vital signs were always verified at intervals inferior to 2 hours in 100\% of the cases assessed, with average arterial blood pressure control and/or central venous blood pressure and/or oxygen saturation.
The degree of dependence was higher for body care and locomotion $(97.6 \%$ of patients with a degree of 5), due to being bed ridden after the procedure.

As for the received therapeutics, $96.9 \%$ used continuous endovenous medication and/or nasogastric, nasoenteral or stoma probes (degrees of dependence 3 and 5).

For eliminations, dependence was also evident, since $95.1 \%$ of the patients needed nursing aid and control when using bedpans, urinals, and when changing disposable diapers and absorbent pads (degree of dependence 4).

Regarding mental state and level of consciousness, most patients (81.1\%) were awake upon arriving at the recovery room, with the use of oxygen, either intermittent or continuous, without the need to clear the airways by $21.3 \%$ of the patients (degree of dependence 2).

Nursing healthcare instructions to patients were readily understood and accepted in $79.9 \%$ of the cases. The indicators of behavior, communication and skin-mucosa integrity showed, mostly, lower levels of complexity a degree of dependence 1 in $96.3 \%, 85.4 \%$ and $90.2 \%$ of the indicators, respectively.

The degree of dependence on nursing care showed by patients in the hemodynamics unit was: $2.4 \%$ requiring minimal care; $87.8 \%$ classified as intermediate care; and $9.8 \%$ as semi-intensive, with the average degree of patients' dependence being $32 \pm 4.8$ points.

The classification varied according to specialty, since gastroenterological patients were rated as needing semiintensive care, with scores varying from 43 to 47 points, averaging at $44,7 \pm 1.4$, being superior to the others $(\mathrm{P}<0.0001)$. Gastroenterology was the only specialty where all patients $(n=7)$ arrived at the recovery room using oxygen.

Cardiology patients were awake upon arrival at the recovery room, with only a few memory deficits. Different from patients seen by gastroenterology, who showed significant differences when compared to other specialties, such as memory loss, absence of motor responses and being unconscious upon arrival $(\mathrm{P}<0.0001)$.

Patients who had undergone cardiac catheterism received a score varying from 30 to 41 points, requiring intermediate and semi-intensive care. As for motility, the patients who had been submitted to cardiological procedures showed higher degrees of dependence when compared to those submitted to neuroradiology and gastroenterology exams $(\mathrm{P}<0.0001)$.

Neuroradiology patients had a degree of dependence of $35.6 \pm 7.3$, also being rated as intermediate. The patients who needed minimal care were those who had not undergone any type of exam $(n=4)$. 
Table 2 - Distribution of the total number of patients seen in a hemodynamics unit, according to the degree of dependence, in each of the critical healthcare indicators, using Perroca's instrument of classification

\begin{tabular}{|c|c|c|c|c|c|c|}
\hline \multirow[b]{2}{*}{ Critical healthcare indicators $* *$} & \multicolumn{6}{|c|}{ Degree of dependence score* $(\%)$} \\
\hline & 1 & 2 & 3 & 4 & 5 & $\begin{array}{c}\text { Total } \\
\%\end{array}$ \\
\hline Mental state and level of consciousness & 81,1 & 6,1 & 4,3 & 1,8 & 6,7 & 100 \\
\hline Oxygenation & 78,7 & 21,3 & 0 & 0 & 0 & 100 \\
\hline Vital Signs & 0 & 0 & 0 & 0 & 100 & 100 \\
\hline Nutrition and hydration & 73,2 & 23,8 & 0,6 & 2,4 & 0 & 100 \\
\hline Motility & 88,4 & 1,8 & 0 & 3,0 & 6,7 & 100 \\
\hline Locomotion & 2,4 & 0 & 0 & 0 & 97,6 & 100 \\
\hline Body care & 2,4 & 0 & 0 & 0 & 97,6 & 100 \\
\hline Eliminations & 2,4 & 0 & 0 & 95,1 & 2,4 & 100 \\
\hline Therapeutics & 2,4 & 0,6 & 96,3 & 0 & 0,6 & 100 \\
\hline Healthcare education & 79,9 & 12,8 & 5,5 & 1,8 & 0 & 100 \\
\hline Behavior & 96,3 & 2,4 & 1,2 & 0 & 0 & 100 \\
\hline Communication & 85,4 & 6,1 & 0,6 & 1,2 & 6,7 & 100 \\
\hline Skin-mucosa integrity & 90,2 & 3,7 & 6,1 & 0 & 0 & 100 \\
\hline
\end{tabular}

When the degree of dependence is cross-referenced with the puncture area, it is possible to observe that the patients who had been submitted to arterial, venous or both types of puncture had a higher degree of dependence than those submitted to exams performed through other ways.

\section{DISCUSSION}

The classification of patients according to their healthcare needs provides a better use of the physical area available as well as of the nursing team, added to lower costs for the hospitals ${ }^{(7)}$. The assessment of patients depends on the nurse, according to the type of healthcare needed: minimal, intermediate, semi-intensive and intensive, so that personnel can be adequately assembled, both qualitatively and quantitatively ${ }^{(8-9)}$.

In this study, the patients' average degree of dependence was classified as $32 \pm 4.8$ points, being in the category of intermediate healthcare, which may vary according to the specialty. Herein, patients requiring intensive healthcare were not observed, supposedly because, when there is an aggravation of the situation, they are transferred to the intensive therapy unit.

The indicators that contributed the most for increased degrees of dependence were locomotion, body care, therapeutic and eliminations - different from another study with 968 patients, wherein $78 \%$ were considered as needing minimal care, about half of them with scores around 1 for locomotion and body care ${ }^{(7)}$. This comparison demonstrates that being restricted to bed is also a decisive factor when determining the degree of dependence.
Around $80 \%$ of the patients showed understanding and acceptance of the healthcare orientations confirmed in literature, which indicates that adequate levels of consciousness and oxygenation suggests better prognostics, favoring self-care ${ }^{(10)}$.

Of the 164 patients in the recovery room of the hemodynamics unit, 109 were submitted to procedures in the cardiology area, demonstrating that $66.5 \%$ of the population has some sort of alteration in the circulatory system. These data were made evident by another study that analyzed 74 medical records, verifying that circulatory system diseases had a $21.6 \%$ incidence ${ }^{(11)}$.

Among the cardiology patients, the procedural way of access (arterial) was the factor with the highest effect on the degree of dependence, due to bed restriction. Among the gastroenterology patients, even though the way of access was oral, these had a high degree of dependence (semi-intensive), due to the type of anesthesia used in the procedure (sedation). Based on these data, we can classify the average hemodynamics unit as one of intermediate healthcare, i.e., made up of patients who depend only partially on nursing care.

\section{CONCLUSION}

The present study contributed for learning about the profile of the patients seen in the recovery room of the hemodynamics unit of this institution, classifying them as needing intermediate healthcare, showing also diversity regarding the type of procedure undergone in the different specialties and the healthcare needs. This study was sent to the head of the department, who, with the 
data presented, could also realize that there is a need to expand this recovery room and increase personnel for

\section{REFERENCES}

1. Gaidzinski RR. Dimensionamento de pessoal de enfermagem. In: Kurcgant P. Administração em enfermagem. São Paulo: Editora Pedagógica e Universitária; 1991. p. 91-6.

2. Antunes AV, Costa MN. Dimensionamento de pessoal de enfermagem em um hospital universitário. Rev Latinoam Enferm. 2003; 11(6):832-9.

3. Ribeiro CM. Sistema de classificação de pacientes como subsidio para provimento de pessoal de enfermagem [tese]. São Paulo: Escola de Enfermagem da Universidade de São Paulo; 1972.

4. Perroca MG, Gaidzinski RR. Sistema de classificação de pacientes: construção e validade de um instrumento. Rev Esc Enferm USP. 1998; 32(2):153-68.

5. Perroca MG, Gaidzinski RR. Análise da validação de constructo do instrumento de classificação de pacientes proposto por Perroca. Rev Latinoam Enferm. 2004; 12(1):83-91.

6. Brasil. Ministério da Saúde. Secretaria de Atenção à Saúde. Portaria no 210 de 15 de junho de 2004 [texto na Internet]. Brasília (DF): Ministério da Saúde; 2004. [citado 2005 Mar the sector, so that the quality of the healthcare provided can be increased.

12]. Disponível em: http://dtr2001.saude.gov.br/sas/ PORTARIAS/Port2004/PT-210.htm

7. Fonseca JP, Echer IC. Grau de dependência de pacientes em relação à assistência de enfermagem em uma unidade de internação clínica. Rev Gaúch Enferm. 2003; 24(3):346-54.

8. Conselho Federal de Enfermagem. Resolução COFEN189/1996. Estabelece parâmetros para Dimensionamento do Quatro de Profissionais de Enfermagem nas Instituições de Saúde. Rio de Janeiro: COFEN; 1996.

9. Laus AM, Anselmi ML. Caracterização dos pacientes internados nas unidades médicas e cirúrgicas do HCFMRPUSP, segundo o grau de dependência em relação ao cuidado de enfermagem. Rev Latino am Enferm. 2004; 12(4):6439.

10. Matsushita MS, Adami NP, Carmagnani MIS. Dimensionamento do pessoal de enfermagem das unidades de internação do Hospital São Paulo. Acta Paul Enferm. 2005; 18(1):9-19.

11. Carmona LMP, Évora YDM. Grau de dependência do paciente em relação à enfermagem: análise de prontuários. Rev Latino am Enferm. 2003; 11(4):468-73. 